\title{
BETWEEN NATIONAL AND INDIGENOUS COMMUNISM. SOME BROAD BRUSHTROKES IN THE POLITICAL BIOGRAPHY OF JUSTAS PALECKIS: 1944-1953 ${ }^{1}$
}

\author{
Vladas Sirutavičius \\ (Lithuanian Institute of History)
}

\begin{abstract}
The article discusses the activities during the period of late Stalinism of Justas Paleckis, the chairman of the Presidium of the Supreme Council of Soviet Lithuania. The paper puts forward the premise that from 1944 to 1953, Paleckis balanced between indigenous (local) communism and attitudes characteristic of some Central European national communists. To be more precise, he tried to emphasise the specifics of the historical development of Lithuania, and its differences from other Soviet republics, in which the formation of the Soviet regime started earlier. According to him, its tradition of statehood made Lithuania a unique republic, and this circumstance should be taken into account when making Lithuania Soviet. Paleckis was convinced that in order to make Soviet rule more attractive to the Lithuanians, it was necessary to cooperate with the nation's cultural elite, that is, with the interwar Lithuanian intelligentsia. In his writings and speeches, he tried to merge organically the liberation of the Lithuanian nation from the 'yoke' of the exploiters, with the no less important liberation from the 'national yoke' or national revival of the Lithuanians. Social and national 'liberation,' according to him, was crowned with the establishment of the socialist order in Lithuania. This 'organic' understanding of history was characteristic of other national communists in Central Europe. Finally, Paleckis tried to incorporate national elements into the system of symbols in Soviet Lithuania. The Lithuanianisation of symbols of Soviet rule was meant to strengthen the legitimacy of the authorities. However, this analysis shows that the Lithuanian Party leadership did not support Paleckis' ideas and efforts. He was often strongly criticised in communist forums. It can be argued that in the period of late Stalinism, the 'window of opportunity' for national communism in Lithuania was finally closed. Tendencies towards unification and Russification became increasingly prevalent in politics. Thus, in this political-cultural context, Paleckis represented the type of communist that could be called an indigenous Lithuanian communist.
\end{abstract}

KEYWORDS: Stalinism; national communism; indigenous communism; national bolshevism; intelligentsia; Communist Party of Lithuania.

${ }^{1}$ The research was funded by a grant (No VAT-02/2010) from the Research Council of Lithuania. The translation was funded by a grant, LIT- $8-5$, from the Research Council of Lithuania. 


\section{Introduction: formulating the problem}

In Western historiography, national communism has been the object of academic debate and research for a long time. The 'Lithuanian version' of national communism has also been touched on, although in a rather fragmentary manner. ${ }^{2}$ An interest in manifestations of national communism has also been observed in recent Lithuanian historiography. ${ }^{3}$

Academic literature has in fact reached an agreement as to what should be considered national communism (or a national communist). According to Martin Malia, in 'political practice', national communism is characterised by a degree of home rule, the rejection of collectivisation, and substantial autonomy granted to the Catholic Church. ${ }^{4}$ The historian formulated this notion of national communism on the basis of the model of 'real socialism' that took shape in Poland. A similar notion can be found in studies by other historians. ${ }^{5}$ Summing up, it is possible to assert that the politics of national communism was distinguished by autonomy and sovereignty as regards the Kremlin. In other words, a national communist was first of all inclined to satisfy the various economic, socio-political and cultural interests of his compatriots, and to do so in certain instances at the expense of the 'centre'. On the other hand, it should be noted that national communism did not have

${ }^{2}$ W.A. Kemp, Nationalism and Communism in Eastern Europe and the Soviet Union. A Basic Contradiction? (London, 1999), pp. 158-171.

${ }^{3}$ S. Grybkauskas, Sovietinè nomenklatūra ir pramoné Lietuvoje 1965-1985 metais (Vilnius, 2011), pp. 111-138; V. Ivanauskas, Lietuviškoji nomenklatūra biurokratinejje sistemoje. Tarp stagnacijos ir dinamikos (1968-1988) (Vilnius, 2011), pp. 497570; V. Sirutavičius, 'National Bolshevism or National Communism: Features of Sovietization in Lithuania in the Summer of 1945 (The First Congress of Intelligentsia)', The Hungarian Historical Review, 1 (2015), pp. 3-28; V. Sirutavičius, 'Istoriko pamąstymai apie Algirdo Juliaus Greimo tautinio komunizmo interpretacijas', Darbai ir dienos, 68 (2017), pp. 7-22; V. Sirutavičius, 'Politinė simbolika stalininejje Lietuvoje. LSSR himnų istorijos 1944 - 1950 m.', Kultūros barai, 11 (2018), pp. 8o-89.

${ }^{4}$ M. Malia, The Soviet Tragedy. A History of Socialism in Russia, 1917-1991 (New York/Oxford, 1994), p. 322.

${ }^{5}$ On the concepts of national communism in historiography, see: V. Sirutavičius, 'Tautinis komunizmas ir jo raiška. Istoriografiniai problemos aspektai', Istorija, 3 (2013), pp. 48-58. 
a consistent political programme based on a specific ideology. In fact, the 'programme' of national communism rested on the provision that the creation of a socialist society could be reconciled with national and cultural interests and the expectations of the titular nation. ${ }^{6}$ Thirdly, conditions for the manifestation of national communism were more favourable in Central European countries which fell into the zone of Soviet influence after the Second World War and became protectorates of Moscow (from 1944 to 1947, for instance, and especially after 1956). During the post-Stalinist period, the leaders of the Soviet Union actually legitimised 'national communism' in their satellites; that is, they approved of the idea and political practice of different national 'paths' in the creation of socialism. However, it should be pointed out that even during that period, the possibilities for the manifestation of national communism were limited, as is shown by the events in 1968 in Czechoslovakia.

The phenomenon of national communism has been examined in the Soviet Union too. Scholars have two explanations for its formation. According to the first, national communism began taking shape fairly early, as a response to Moscow's policy of centralism and unification, which was seen by some Party activists as wrong and violating the independence of the Soviet republics. As a rule, national communists emphasised the need to solve the national question along with the creation of the Soviet system, they supported the expansion of the culture of titular nations, they supported the preservation of the rights of the Soviet republics, and some even advocated the establishment of separate communist

\footnotetext{
${ }^{6}$ The idea that it was possible to reconcile 'nationalism' with 'communist ideology'originated in Moscow at the very beginning of the Second World War. In May 1941 the Bulgarian communist Georgi Dimitrov, the head of the Comintern, noted in his diary: 'We will have to develop an idea of combining a healthy, properly understood nationalism with proletarian internationalism. Proletarian internationalism should be instilled in such a nationalism in individual countries. Comrade Stalin made it clear that there could be no contradictions between properly understood nationalism and proletarian internationalism. Ruthless cosmopolitanism that denies national feelings and the notion of a homeland has nothing in common with proletarian internationalism.' Quoted from J.C. Behrends, 'Nation and Empire: Dilemmas of Legitimacy during Stalinism in Poland (1941-1956)', Nationalities Papers, 4 (2009), p. 446.
} 
parties. ${ }^{7}$ The second explanation claims that national communism emerged because of the political evolution of the Soviet system. In other words, as the Soviet system was becoming more liberal, conditions emerged for the manifestation of the independence and autonomy of the ruling elite of the Soviet republics. ${ }^{8}$ It should be noted, though, that the conditions for the manifestation of the autonomy of subjects of the Soviet Union (and first of all, of the Soviet republics) were very limited. This was primarily due to the domination of a unified and centralised Communist Party in the political system. For this reason, historians find it expedient to distinguish national communism from indigenous communism. ${ }^{9}$ The policy of indigenous (or local) communism was characterised by the aspiration to satisfy, primarily, the various socio-economic interests of one's 'own' region or republic, giving preference to the culture of the titular nation, but without the aspiration to expand 'the republic's sovereignty'.

There is another observation of a methodological nature. Historians point out that as early as the 1930s, in order to consolidate the legitimacy of the regime, the leadership of the Soviet Union began to 'mask the Marxist-Leninist world-view with Russo-centric etatist rhetoric.'10 Such tendencies in the cultural policy of the Soviet Union under Stalin were called national Bolshevism (or national Stalinism) by historians." The actual purpose of this policy was to render the regime more acceptable to the titular nation, and thus to facilitate the Sovietisation of societies by incorporating the national cultural heritage, national heroes and symbols, that is, nationalism in its broadest sense, into the Soviet system. For this reason, historiography

${ }^{7}$ R. Pipes, The Formation of the Soviet Union. Communism and Nationalism 1917-1923 (Cambridge, London, 1997), pp. 242-293; J.E. Mace, Communism and the Dilemmas of National Liberation: National Communism in Soviet Ukraine, 1918-1933 (Cambridge, 1983).

${ }^{8}$ A.J. Motyl, Sovietology, Rationality, Nationality: Coming to Grips with Nationalism in the USSR (New York, 1990), pp. 87-102.

${ }^{9}$ Z. Brzezinski, The Soviet Bloc. Unity and Conflict (Harvard, 1981), p. 62.

${ }^{10}$ D. Brandenberger, National Bolshevism. Stalinist Mass Culture and the Formation of Modern Russian National Identity, 1931-1956 (Cambridge, London, 2002), p. 6.

${ }^{11}$ E. van Ree, 'The Concept of "National Bolshevism": an Interpretative Essay', Journal of Political Ideologies, 3 (2001), pp. 289-307. 
frequently distinguishes between national bolshevism and national communism. To put it simply, the attitude of the former to ethnic culture and the cultural heritage was pragmatic, utilitarian and frequently nihilistic; while the latter considered the values of ethnic culture significant, with a place in the socialist system. And yet even scholars who emphasise the difference between the two policies also notice that the relationship between them was fairly 'dialectic', that is, one could easily 'turn into' the other. ${ }^{12}$

There have already been some reflections on Justas Paleckis' 'national communism' in Lithuanian historiography. It has been noted that, compared to other figures in the Lithuanian Communist Party, he was distinguished not only by his liberalism, but also 'quite often voiced his dissatisfaction with the policy of Russification', and eventually was 'a communist of national consciousness'. These observations, however, are of a fragmentary nature, and lack in-depth development. ${ }^{13}$ In Lithuanian historiography, the dispute in 1950 among the leadership of the Lithuanian Communist Party, in which Paleckis took part, is discussed in greater detail. ${ }^{14}$ The subject of the dispute was how to resolve issues of education arising in Polish-populated districts of eastern Lithuania. In the opinion of Paleckis and Mečislovas Gedvilas, who was the head of the Lithuanian government, after the repatriation of the Poles, those Poles who remained in the Vilnius region were just Polonised Lithuanians, and their further Polonisation by developing education in the Polish language would not have been useful. The Party discussions and practical politics were won by a different point of view, which was based on 'proletarian internationalism'.

${ }^{12}$ V. Tismăneanu, Stalinizm na każdą okazję. Polityczna historia rumuńskiego komunizmu (Kraków, 2010), pp. 37-40.

${ }^{13}$ V. Tininis, Sovietiné Lietuva ir jos veikejjai (Vilnius, 1994), pp. 214-215; L. Truska, Lietuva 1938-1953 metais (Kaunas, 1995), pp. 134-135; V. Kašauskienė, Istorijos spąstuose. Justo Paleckio gyvenimo ir veiklos bruožai 1899-1980 (Vilnius, 2014), pp. 497-504.

${ }^{14}$ V. Stravinskienė, 'Lietuvių ir lenkų santykiai Rytų ir Pietryčių Lietuvoje: 1944 m. antra pusè-1953 m.', Lietuvos istorijos metraštis, 2007/2 (2008), pp. 95-96; A. Streikus, 'Sovietinio režimo pastangos pakeisti Lietuvos gyventojų tautinị identitetą', Genocidas ir rezistencija, 1 (2007), pp. 22-23; J. Rudokas, 'Tarybinė Vilnijos polonizacija 19501956 metais', Gairès, 7 (2011), pp. 17-18. 
A good example of how Paleckis thought he would be able to combine social and political radicalism with Lithuania's national aspirations was 'Lietuvos laisvos darbo respublikos kūrimo programa' (Programme for the Creation of Lithuania as a Free Republic of Labour), which he wrote as early as the autumn of 1939. The programme speaks for a fairly radical transformation of Smetona's authoritarian political regime, but does not call for the Sovietisation of the political system. On the other hand, it speaks not so much on behalf of the Lithuanian nation as on behalf of 'the Lithuanian people'. In other words, it is about a community that is defined more by the class aspect, and not the national aspect. Also, from a geopolitical point of view, the future Lithuania as a republic of labour was projected by Paleckis as a protectorate of the USSR. ${ }^{15}$ In fact, this political programme matched the views of the People's Front that were promoted and actively supported by Moscow and the Comintern. The idea of the People's Front was popular in the second half of the 1920s among young populists who were led by Paleckis. ${ }^{16}$

The paper puts forward the idea that from 1944 to 1953, Paleckis balanced between indigenous (local) communism and attitudes characteristic of some Central European national communists. To be more precise, he tried to emphasise the specifics of the historical development of Lithuania, and its differences from other Soviet republics, in which the formation of the Soviet regime started earlier. According to him, its tradition of statehood made Lithuania a unique republic, and this should be taken into account when making Lithuania Soviet. Paleckis was convinced that in order to

${ }^{15} \mathrm{~J}$. Paleckis, Ieškojome tikru keliu (Vilnius, 1987), pp. 134-136.

${ }^{16}$ According to young populists (Mečislovas Gedvilas, Petras Kežinaitis, Juozas Vaišnoras, Albertas Knyva, Valerijonas Knyva, Julius Būtėnas, Aleksandras Drobnys, Marijonas Gregorauskas, Aleksandras Tornau, and others), the main threat to the Lithuanian nation was Nazi Germany and its expansionist policy. At the same time, the young populists considered the Soviet Union the main ally of Lithuania. Therefore, they cooperated with the Communist Party of Lithuania. Juozas Vaišnoras, 'Prisiminimai iš Liaudies fronto organizavimo ir veiklos', 1966, Lietuvos Ypatingasis archyvas LKP skyrius (Lithuanian Special Archives Communist Party of Lithuania archive; LYA LKP), col. 3377, inv. 46, file. 964, p. 13-20. M. Tamošaitis, 'Justas Paleckis ir jaunieji valstiečiai liaudininkai', Vilniaus istorijos metraštis (Vilnius, 2007), pp. 137-16o. 
make Soviet rule more attractive to the titular nation, the Lithuanians, it was necessary to attract the nation's cultural elite, that is, the intelligentsia from the period between the wars. Paleckis also tried to merge organically the liberation of the Lithuanian nation from the 'yoke' of the exploiters, that is, the struggle for social justice, with the no less important liberation from the 'national yoke', or with the period of the national revival. It goes without saying that the liberation was crowned by the establishment of the socialist order in Lithuania. This 'organic' understanding of history was also characteristic of other national communists in Central Europe. ${ }^{17}$ Finally, Paleckis tried to incorporate national elements into the system of symbols of Soviet Lithuania. The Lithuanianisation of the symbols of Soviet rule was meant to strengthen its legitimacy. The communists of Central European countries were led by a similar logic in their policies between 1944 and $1947 .^{18}$

The 'unique situation' of Lithuania, and calls for the inclusion of the 'old' intelligentsiain the creation of socialism

Paleckis' speeches at the bureaus of the Central Committee of the Lithuanian Communist (Bolshevik) Party and its plenary sessions contain statements in which he emphasised the necessity of taking into account 'specific' Lithuanian conditions while creating the socialist order. According to him, the mechanical transfer of the experience of the creation of the new social order from other Soviet republics and nations to Lithuania would be impossible. On the other hand, it should be noted that, just like other leaders of

${ }^{17}$ Y. Sygkelos, 'The National Discourse of the Bulgarian Communist Party on National Anniversaries and Commemorations (1944-1948)', Nationalities Papers, 4 (2009), p. 426.

${ }^{18}$ M. Zaremba, Komunizm, legitymizacja, nacjonalizm. Nacjonalistyczna legitymizacja wtadzy komunistycznej w Polsce (Warszawa, 2001), pp. 135-173; M. Mevius, Agents of Moscow. The Hungarian Communist Party and the Origin of Socialist Patriotism 1941-1953 (Oxford, 2004), pp. 87-110; S. Pons, 'Stalin and the European Communists after World War Two (1943-1948)', Post-war Reconstruction in Europe. International Perspectives, 1945-1949, eds. M. Mazover et al. (New Haven, London, 2011), pp. 124-129. 
the Lithuanian Communist Party, Paleckis stressed the need for the struggle against 'bourgeois nationalists', spoke of the need to inculcate Soviet patriotism, and emphasised the positive role of the Russian nation in Lithuanian history. All these plots were closely intertwined in his speeches.

For instance, at the 4th Plenary Session of the Central Committee of the Lithuanian Communist (Bolshevik) Party in December 1944, the decree 'On the Shortcomings and Aims of the Political Work of the Party Organisation of the LSSR', adopted by the Central Committee of the All-Union Communist (Bolshevik) Party on 30 October 1944, was discussed. In it, Moscow voiced its rather strict criticism of the leadership of the Lithuanian Communist Party regarding various 'shortcomings and errors' in its activities (the main one being the inadequate struggle against 'bourgeois nationalists'), which pointed to the Party's inability to control the socio-political situation in the republic. Some organisational conclusions were also arrived at: a Lithuanian bureau of the All-Union Communist (Bolshevik) Party was established in November, and Mikhail Suslov was appointed its chairman. ${ }^{19}$ (Paleckis, who was chairman of the Presidium of the Supreme Council of the Lithuanian Soviet Socialist Republic, was not a member of the bureau.) The bureau became the main political institution in the Lithuanian SSR, and practically all important decrees from the Lithuanian Communist Party, the Soviet of People's Commissars and the Presidium of the Supreme Council were passed with its approval. ${ }^{20}$ The establishment of this institution pointed to the strengthening of the centralist-unification political trend in Lithuania.

Paleckis also spoke at the plenary session. ${ }^{21}$ Like other participants, he called for a more active struggle against 'bourgeois nationalists' ('more anger against the enemy'). At the same time, he explained that 'Lithuania's situation is unique'. For a long time,

${ }^{19}$ Е. Зубкова, Прибалтика и Кремль 1940-1953 (Москва, 20о8), pp. 139-142.

${ }^{20} \mathrm{H}$. Šadžius, 'VKP (b) CK Lietuvos biuro veikla organizuojant tautinio pasipriešinimo slopinimą', Lietuvos istorijos metraštis 1997 (Vilnius, 1998), pp. 241-242.

${ }^{21}$ Transcript of the 4th plenum of the Central Committee of the Lithuanian Communist (Bolshevik) Party. Justas Paleckis' speech, LYA LKP, col. 1771, inv. 7, file 10, p. 149-157. 
it had been a 'bourgeois-kulak' republic, which influenced people's psychology. The Second World War had sharpened 'national feeling'. 'Healthy patriotism' played an important role in the liberation from the Nazi occupation, and encouraged resistance against the German invaders. However, Paleckis stated that next to this 'patriotism', there was 'chauvinism', as 'bourgeois nationalists' were saying that Lithuania was being Russified, and the Lithuanian language and culture were being suppressed. Paleckis' view was that in order to reduce the influence of the 'bourgeois nationalists', Soviet rule had to develop Lithuanian culture, thus demonstrating the prospects it was granting the Lithuanian nation. He said that the sharpened national feeling' had to be directed towards Soviet patriotism, and in order to achieve this, a well-thought-out national policy had to be implemented. One feature of this policy was the 'attraction' of the old prewar Lithuanian intelligentsia. ${ }^{22}$ In Paleckis' view, all these measures would help to legitimise Soviet rule, and would make it more 'national' and attractive to many Lithuanians.

His evaluations and suggestions were well substantiated. During the summer and early autumn of 1944, the Lithuanian Communist Party was facing a 'crisis of legitimacy'. Reports sent by activists of Soviet rule from the provinces to Vilnius pointed to one important fact: the Lithuanians did not trust Soviet rule. In some reports, the reason for the mistrust was explained by its 'anti-national nature'. 'A large part of the nation think that there is no Lithuanian rule at all, everything is done by the Russians. ${ }^{23}$

Thus, it can be presumed that Paleckis was trying to impart a Lithuanian character to Soviet rule. In other words, he concerned himself not only with the Sovietisation of Lithuania, but also with the preservation of the Lithuanian spirit. This trend in his activities was also apparent later, for example in 1946. In the summer of that

${ }^{22} \mathrm{~V}$. Kašauskienè, Istorijos spastuose ..., pp. 474-496.

${ }^{23}$ The note from V. Sakalauskas, the secretary of the Lithuanian Communist (Bolshevik) Party of the Alytus district, to Antanas Sniečkus, 2 August 1944, LYA LKP, col. 1771, inv. 7 , file 148, p. 52-53; the note from Grigonis, the secretary of the Lithuanian Communist (Bolshevik) Party of the Seiniai province, to the head of the Information Department of the Central Committee of the Lithuanian Communist (Bolshevik) Party, 22 September 1944, LYA LKP, col. 1771, inv. 7, file 150, p. 41; K. Štuikevičius' report about the situation in the Siesikai rural district of the Ukmerge district, 15 September 1944, LYA LKP, col. 1771, inv. 7, file 150, p. 118-118ap. 
year, in August, the Central Committee of the All-Union Communist (Bolshevik) Party passed a decree which started a campaign in the ideological struggle against the intelligentsia, its 'subservience to the West', and 'cosmopolitism'. Important elements of this campaign were the encouragement of Russian-based Soviet patriotism, and the struggle against 'bourgeois nationalism'. At that time, the chances of being accused of the 'propagation of bourgeois nationalism' markedly increased, not only for the intelligentsia, but also for various Party functionaries in national republics. ${ }^{24}$ So Paleckis spoke of the importance of the Lithuanian spirit in the creation of Soviet Lithuania in this particular ideological-political context.

In November, the plenary session of the Lithuanian Communist Party considered the decree 'On the Activities of the Central Committee of the Lithuanian Communist (Bolshevik) Party', which was passed by the Central Committee of the All-Union Communist (Bolshevik) Party on 5 October 1946. In this decree, the Lithuanian Communist Party was criticised for its inadequate struggle against 'bourgeois nationalism'. It was also ordered to encourage 'the creation of its own Soviet intelligentsia'. 25

Paleckis spoke on these issues at the plenary session, but in a very particular manner. ${ }^{26}$ In his opinion, there were several main reasons for the failures of the Lithuanian Communist Party, which attracted 'just' criticism from the Central Committee of the All-Union Communist (Bolshevik) Party. 'Our knowledge of the theory of Marxism-Leninism is inadequate,' he said. 'The Lithuanian Communist Party and its Central Committee have failed to assess

\footnotetext{
${ }^{24}$ In June 1946, a special group of party functionaries from Moscow inspected the Party committee of Kaunas. Juozas Grigalavičius, the secretary of the Kaunas Party organisation and the deputy chairman of the Presidium of the Supreme Council, was accused of not fighting 'the national bourgeois underground' and of ignoring Russian Party members. Grigalavičius and several other leaders of the Kaunas Party organisation (Lithuanians) were removed from their posts. Note about the removal of Grigalavičius (June 1946), LYA LKP, col. 1771, inv. 9, file 247, p. 25-26; J. Grigalavičius, Kai Lietuvoje šeimininkavo stalinistai, pp. 21-78.

${ }^{25}$ Communist Party Orgbureau meeting, 5 October 1946, Российский государственный архив социально-политической истории (Russian State Archive of Social and Political History, РГАСПИ), col. 17, inv. 116, file 277, p. 14.

${ }^{26}$ Paleckis' speech to the party plenary session, 22-24 November 1946, LYA LKP, col. 1771, inv. 9, file 17, p. 338-343.
} 
the specifics of Soviet Lithuania on the basis of Marxist-Leninist analysis.' On this occasion, Paleckis reminded the participants in the plenary session about Lenin's directive of 1921, addressed to Caucasian communists. In it, the Caucasian communists were warned against 'copying the tactics of the RSFSR, and were invited to take into account the actual conditions', to demonstrate 'more caution, mildness and more concessions to the petty bourgeoisie, the intelligentsia and the peasantry ...' It was 'a more cautious and more systematic transition to socialism ...'

After that, Paleckis discussed the main features of the 'specifics' of Lithuania, which included: the agrarian nature of the country, the inconsiderable working class, the tradition of 'bourgeois statehood', the relatively young modern Lithuanian culture, the fact that most Lithuanian intellectuals were of kulak descent, the formidable legacy of the Nazi occupation and the anti-Soviet propaganda of that period, the negative role of the Catholic Church, and finally the absence of experienced cadres devoted to Soviet rule. In his opinion, all those factors gave rise to various 'complications': bourgeois nationalism, an escalation of the class struggle, reactionary moods among the intelligentsia, and others. Lithuanian communists faced problems that did not exist in other republics, where the creation of socialism was started earlier. Paleckis summed up this part of his speech with the following thought: 'Our path to socialism will no doubt have its peculiarities. We will repeat some stages in it, and possibly skip others.'

At the same time, Paleckis stressed that the Central Committee of the All-Union Communist (Bolshevik) Party and the All-Union government took into account the peculiarities of Lithuania. In his view, 'Stalin showed sensitivity in his approach to the issue of Vilnius as the capital of Soviet Lithuania, the issue of the Lithuanian port of Klaipèda, and some Poland-related issues.' Another instance of these policies was 'the history of our Lithuanian national anthem'. According to Paleckis, at the beginning, the possibility of Vincas Kudirka's Tautiška giesme (National Song) becoming the anthem of the Lithuanian SSR was very remote. When, however, the Central Committee of the All-Union Communist (Bolshevik) Party and Stalin himself heard of this idea, the issue was resolved positively. 
There were several reasons for the decision of the leadership of the Soviet Union to declare the anthem of the Republic of Lithuania the anthem of Soviet Lithuania. The first was to improve the prestige and popularity of Soviet rule among the Lithuanians, and primarily among the old prewar intelligentsia. Another reason was that, in the opinion of leaders in Moscow, the promotion of Soviet Lithuanian statehood had to remove the issue of the annexation of the Republic of Lithuania from the international political agenda. It has been observed in Lithuanian historiography that from about the middle of 1943, there were obvious attempts in the politics of the Soviet Union to 'raise' the Republic of Soviet Lithuania to international politics by simultaneously removing, in a variety of ways, the Republic of Lithuania from the international arena. ${ }^{27}$ At approximately the same time, manifestations of 'national aspects' were becoming stronger in the leadership of the Lithuanian SSR: banned in 1940, the interwar national anthem of Lithuania began to be broadcast in Lithuanian programmes on Moscow radio. ${ }^{28}$ Concerns were voiced regarding the use of the Lithuanian language in the administrative-bureaucratic apparatus. ${ }^{29}$ Early in 1944, the Soviet leadership considered the possibility of restoring the republic's diplomatic service, and in the autumn of 1944, Soviet Lithuania, along with Ukraine and Belarus, was proposed as a member of the United Nations Organization. ${ }^{30}$ However, Moscow's policy of the promotion of 'the statehood of Soviet Lithuania' and its manifestations was rather short-term, and continued until the beginning of 1945 .

${ }_{27}^{27}$ Ч. Лауринавичюс, 'Вводная статья', СССР и Литва в годы второй мировой войны. Сборник документов, сост. А. Каспаравичюс, Ч. Лауринавиюс, Н. Лебедева, т. 2 (Вильнюс, 2012), pp. 42-43.

${ }^{28}$ Paleckis very actively supported the idea of preserving Vincas Kudirka's Tautiška giesme as the anthem of Soviet Lithuania. According to his diary, he started to discuss the idea with Soviet leaders at the beginning of 1944: . Paleckis, Pergales saliutas (Vilnius, 1985), p. 105. Eventually, the Communist Party of Lithuania decided 'to turn Tautiška giesme (the anthem of the Republic of Lithuania) into an instrument which could strengthen the Soviet government'. Resolution project and resolution of the Central Committee of the Lithuanian Communist Party, 21 June 1944, LYA LKP, col. 1771 , inv. 7 , file 267 , p. 41.

${ }^{29}$ Decision of the Council of People's Commissars of the Lithuanian SSR No 49, Moscow, 28 April 1944, LYA LKP, col. 1771, inv. 7, file 28, p. 17 .

$3^{\circ}$ Ч. Лауринавичюс, 'Вводная статья ...', p. 43. 
In Paleckis' understanding, the issue of cadres was also very important for the consolidation of Soviet power. He supported the line of the All-Union Communist (Bolshevik) Party, which stressed the need to speed up the nurturing of a new Soviet intelligentsia, the 'cleansing' of the 'unreliable', and the promotion of people of working class or peasant origin to leading positions. At the same time, he was an ardent advocate of the 'employment of bourgeois specialists', because they played an important role in 'rebuilding Soviet Lithuania.' 'Without them, we would not have achieved what we have now,' he said. They were to be treated with caution and responsibility. Paleckis maintained that 'old cadres' were frequently treated in too bureaucratic a manner, and without an appreciation of their knowledge and skills, which brought about increased 'cadre fluctuation'. He was convinced that a knowledge of the local conditions and the language, the possibility to communicate and carry out social duties among the local population, were important qualities for working in Lithuania. ${ }^{31} \mathrm{He}$ was critical of the new arrivals from other Soviet republics. According to him, these newcomers were ignorant of the conditions and the country's past, and so were distrustful of everybody. They were inclined to keep 'on the safe side', but this harmed Soviet rule. In conclusion, he observed that the ongoing 'cleansing' of unreliable personnel simultaneously caused their 'de-Lithuanianisation', and as a consequence, smaller numbers of Lithuanian executive cadres. For this reason, it was crucial to 'promote' local national cadres.

Paleckis' speech at the plenary session was harshly criticised by Antanas Sniečkus. According to the leader of the Lithuanian communists, the term 'de-Lithuanianisation' was wrong, because it slandered the Party. Cadres were to be formed from peasants and workers. A loyal Soviet apparatus could only be formed through a struggle, which, according to Sniečkus, was a path to 'cleansing'. According to Sniečkus, Paleckis was wrong when speaking about re-education. 'Those who were pillars of bourgeois power cannot

${ }^{31}$ Transcript of the plenary session of the Central Committee of the Lithuanian Communist Party, 22-24 November 1946. J. Paleckis' speech, LYA LKP, col. 1771, inv. 9, file 17 , p. 339 . 
be re-educated. ${ }^{32}$ The leader of the Lithuanian Communist Party finally accused Paleckis of not doing any practical work, and demanded that he admit his mistakes. Towards the end of the plenary session, Paleckis did admit his mistakes. ${ }^{33}$

However, not intending to surrender so easily, or possibly in order to protect himself, in January 1947, Paleckis wrote a letter to Andrei Zhdanov. In it, he wrote that frequently 'our specifics are not taken into account', some people 'do not understand our conditions, urgent questions were not answered, while law-and-order problems were ignored' ${ }^{34}$ All this hindered the consolidation of Soviet rule in Lithuania. Summing up the most important parts of his speech at the plenary session, he stressed that he focussed on the issue of national cadres. 'In the struggle against the nationalists, we need to use bourgeois specialists, to win them over to our side, and to re-educate them,' he wrote. At the same time, he admitted the existence of 'lame formulations' in his speech, and the hostile reaction to it by the leadership of the Lithuanian Communist Party. He admitted his mistakes at the plenary session. At the end of the letter, Paleckis wrote that the leadership of the republic lacked

${ }^{32}$ Paleckis' ideas were also criticised by the inspectors from Moscow: the report of the instructors Kozlov and P. Kovanov of the Propaganda and Agitation Department of the Central Committee of the All-Union Communist (Bolshevik) Party to N.S. Patolichev, the secretary of the Central Committee of the All-Union Communist (Bolshevik) Party, 11 December 1946, РГАСПИ, col. 17, inv. 125, file 405, p. 123-124 (see also Lietuvos Ypatingasis Archyvas KGB dokumentų skyrius (Lithuanian Special Archives, KGB document archive, LYA KGB), col. K8, inv. 3, microfilm). A strict position towards 'the old Lithuanian intelligentsia' was taken by the vast majority of Lithuanian Communist Party apparatus personnel. Mistrust and even hostility towards the interwar intelligentsia was also demonstrated by various newcomers from the Soviet Union and by All-Union Communist Party Central Committee apparatchiks. In the autumn of 1944, two inspectors from the Cadre Department of the All-Union Communist Party criticised Soviet Lithuania's leaders for their overly loyal attitude towards the 'bourgeois intelligentsia'. See: Lietuvos sovietizavimas 19441947 m.: VKP (b) CK dokumentai, ed. by M. Pocius (Vilnius, 2015), pp. 119-127.

${ }^{33}$ Transcript of the plenary session of the Central Committee of the Lithuanian Communist Party, 22-24 November 1946. J. Paleckis' speech, LYA LKP, col. 1771, inv. 9, file 17, p. 479 .

${ }^{34}$ Technical secretariat of the Central Committee of the All-Union Communist (Bolshevik) Party, J. Paleckis' letter to Andrei Aleksandrovich (Zhdanov), 17 January 1947, РГАСПИ, col. 17, inv. 121, file 588, p. 1-3. 
unity on the most important issues, and asked Zhdanov to receive them (Paleckis, Sniečkus and Gedvilas) to discuss these issues. However, it is not clear what Zhdanov wrote in reply, or whether a meeting with the leaders of Lithuania took place.

There were more episodes in Paleckis' activities when he sought the 'advice' of top Party officials in Moscow. In December 1947, he again appealed to Zhdanov for advice on what he should do. This time, it was about his book Paskutinis caras (The Last Tsar), which he had written during the interwar period, and excerpts of which had appeared in Laisve (Freedom), the newspaper of 'progressive' American Lithuanians. He confessed to Zhdanov that he was not acquainted with the foundations of Marxism when he wrote the book. For this reason, it should have been revised extensively before its publication, but nobody had discussed publishing matters with him. ${ }^{35}$ The question of what was to be done was resolved in the spring of the following year. After an investigation, Paleckis' book was recognised as 'harmful and politically wrong'. For this reason, he was advised to 'criticise' the book in the same newspaper. Also, measures were to be taken to remove it from the libraries of the Lithuanian SSR. ${ }^{36}$ On another occasion, in 1950, Paleckis appealed for 'assistance' from Moscow officials. This time, he wanted to find out whether his poem 'Our Stalin', which he wrote in 1949 to mark Stalin's 7oth birthday, was suitable for publication. (A small extract from the poem appeared in the newspaper Tiesa (The Truth.)) The author hoped to publish his work in the all-Union press. This time, Paleckis addressed Alexander Poskrebyshev, Stalin's secretary. ${ }^{37}$ We can presume that these appeals were not just a demonstration of loyalty or respect for 'senior party comrades'. It is very likely that he was seeking the protection of senior Moscow officials, and at the same time protection against various political 'surprises'.

${ }^{35}$ Paleckis' letter to Andrei Zhdanov, 17 December 1947, РГАСПИ, col. 17, inv. 125, file 6o8, p. 1.

${ }^{36}$ L. Ilyichev's letter to Mikhail Suslov, 25 May 1948, ibid., p. 6-7.

${ }^{37}$ Paleckis' letter to A. Poskrebyshev, 23 June 1950, РГАСПИ, col. 17, inv. 132, file 409, p. 130-135. See also LYA KGB, col. K8, inv. 3. microfilm. 


\section{The interpretation of the history of the Lithuanian nation}

The contours of Paleckis' notion of the history of the Lithuanian nation can be found in the speech he gave at the First Congress of the Lithuanian Intelligentsia in June $1945 .^{38}$ Among the participants and speakers at the congress, there were prominent figures in Lithuanian culture and science from the interwar period: Professor Jonas Kairiūkštis, the academician Juozas Matulis, Professor Kazimieras Bieliukas, the theatre director Borisas Dauguvietis, the academician Pranas Mažylis, Profesor Jonas Dagys, Karolis Račkauskas-Vairas, Monika Mironaitė, Juozas Kupčinskas, Julius Būtėnas, Professor Viktoras Ruokis, the writers Balys Sruoga and Ieva Simonaitytė, Professor Paulius Slavėnas, and others. According to Mikhail Suslov, the congress aimed at 'the consolidation of influence among the intelligentsia. By organising the congress, the leadership in Lithuania intended to involve the old, interwar intelligentsia in the creation of Soviet Lithuania, and to demonstrate that the intelligentsia were supporting Soviet rule. ${ }^{39}$ It has to be admitted that the delegates not only voiced support at the congress. Some were critical of the authorities and made various demands of it, and formulated conditions for their support of the Soviet government. The main demand was that the authorities should take into account the cultural expectations of the Lithuanian nation, and create conditions for the development of the national culture..$^{\circ}$

Paleckis' notion of history was based not only on the idea of the class struggle and the struggle for 'people's liberation from

${ }^{38}$ Tiesa, 18 July 1945, No 166 . See also V. Sirutavičius, 'National Bolshevism or National Communism ..., pp. 10-24.

${ }^{39}$ Mikhail Suslov's letter to Georgy Malenkov, 22 May 1945, РГАСПИ, col. 597, inv. 1, file 16, p. 45 (also LYA KGB, f. K8, inv. 3, microfilm). Suslov's report to Stalin, 20 July 1945, РГАСПИ, col. 597, inv. 1, file 2, p. 115.

${ }^{40}$ Matas Mickis, the rector of the Agriculture Academy, and the Vilnius University professor Jonas Dagys were particularly critical of the government's policy. At the end of the congress, Juozas Matulis proposed that a statement about the Lithuanianisation of Vilnius should be included in the final document, 'An Appeal to the Lithuanian Intelligentsia'. After Polish citizens had left Vilnius, announced Matulis, the Soviet Lithuanian government had to 'Lithuanianise the city'. The delegates supported the idea with 'long applause'. This episode was omitted by the official press. 
social oppression', but also on the struggle for the liberation of the Lithuanian nation from national oppression. These two stages in the liberation of the Lithuanians were closely interrelated. Within this concept of history, the period of 'national liberation' was an important stage in the history of the nation. The nation's social and national liberation was organically crowned by the creation of Soviet Lithuania.

According to Paleckis, the struggle for national liberation coincided with 'the struggle of Lithuanian peasants against the exploiter landlord'. This struggle resulted in a new intelligentsia that did 'the progressive work of awakening the Lithuanian national consciousness'. The pioneers of this movement were Vincas Kudirka and Vincas Mickevičius-Kapsukas. According to Paleckis, they were not content with the 'aspirations of national romanticism', but launched 'a struggle for the real issues of the Lithuanian nation', such as 'liberation from tsarism and the landlords' yoke, for their rights and land'. For this reason, Kudirka and Mickevičius-Kapsukas played a special role in the history and culture of Lithuania. Neither of them was detached 'from the needs of the Lithuanian nation', and fought for them actively.

Meanwhile, in Paleckis' opinion, 'the founders of bourgeois Lithuania' had turned their backs on that 'progressive trend', while interwar Lithuania was created by bankers and landlords, that is, by lords. ${ }^{41}$ According to him, that Lithuania was not what it was in the dreams of Basanavičius, Kudirka and Maironis. To prove his thesis, he cited a stanza from a poem by Maironis: 'Lithuania, the land of heroes / We have sung it for a long time / But from this glory / Only devils draw their well-being'. Paleckis was convinced that the development of the Lithuanian intelligentsia took a meaningful turn in 1940, because it was given the opportunity to 'march together with the people'. He finished his speech by saying how the new power ensured the 'rise of culture and the well-being

${ }^{41}$ In the political manifesto 'Lithuania Free Labour Republic', Paleckis stated that modern Lithuania was established on the principles of 'people's democracy'. These principles were approved by the Constituent Assembly. Later, however, the Lithuanian government rejected the idea of people's democracy, and the state became 'a landlords' republic'. Lithuania began to imitate the 'worst example, that of Poland': J. Paleckis, Ieškojome kelių tikru (Vilnius, 1987), pp. 134-136. 
of the Lithuanian nation', and by describing the new 'dynamism' characteristic of the new, Soviet, Lithuanian culture: the active 'highlighting' of talents spotted in the masses, the organisation of a song festival, commemorations of various anniversaries of great Lithuanian writers, preparations for the celebration of the 4ooth anniversary of the first Lithuanian book, and so on.

Various aspects of the organic notion of the history of Lithuania as formulated by Paleckis become clearer when compared with the interpretations by Antanas Sniečkus, another leader of Soviet Lithuania, and the first secretary of the Lithuanian Communist Party. Sniečkus' speech at the congress did not contain the historical inserts characteristic of Paleckis' speech. It was dominated by an interpretation based on the principles of the class struggle and proletarian internationalism. ${ }^{42}$ A similar concept of history was set out in Sniečkus' other works. In his booklet Lietuviu tautos kovos kelias dèl savo laisves ir nepriklausomybes (The Path of the Lithuanian Nation's Struggle for its Freedom and Independence), the history of the nation begins with the October Revolution. ${ }^{43}$ According to Sniečkus, it was the socialist revolution in Russia that created the grounds for the implementation of the principle of the 'sovereignty of the nation', while the state was steered by 'the genuine nation of workers and peasants'. Sniečkus completely ignored the period of the Lithuanian national revival. He voiced similar ideas in his other works from that period. ${ }^{44}$

It should be said that, despite the differences, Paleckis' and Sniečkus' concepts of the history of the Lithuanian nation shared some important similarities. They both emphasised the positive and civilising impact of Russia and the Russians on the history of Lithuania. According to both, this impact manifested itself in different ways: thanks to Russia/the Soviet Union, the Lithuanians preserved their ethnic-cultural identity, for it was the USSR that protected them from the Nazis. Also, only thanks to the Soviet

${ }^{42}$ Tarybų Lietuvos inteligentijos uždaviniai, red.J. Šimkus (Vilnius, 1947), pp. 45-69.

${ }^{43} \mathrm{~A}$. Sniečkus, 'Lietuvių tautos kovos kelias dèlsavolaisvèsir nepriklausomybės' (Vilnius, 1946), LYA LKP, col. 77, inv. 28, file 10284.

${ }^{44}$ A. Sniečkus, M. Gedvilas, Lietuvių tauta kovoje už laimingą ateiti (Kaunas, 1947, pp. $3^{-12}$. 
Union was the Lithuanian SSR capable of resolving the urgent issue of the integrity of its territory. "The Lithuanian lands were merged, and Vilnius and Klaipėda became part of our republic's territory. ${ }^{45}$ Thus, if the perception of the significance of the 'Lithuanian national revival' divided the two attitudes to the history of the Lithuanians, the elucidation of the positive civilising mission of Russia/the USSR regarding the Lithuanians made them similar.

On the other hand, it should also be noted that not in all works by Paleckis was the importance of the period of the national revival portrayed in the same manner. In Tarybu Lietuvos kelias (The Path of Soviet Lithuania), a booklet published in the late 1940s, he only hinted at the national movement, by mentioning its symbols, the newspapers Aušra and Varpas. Instead, he highlighted the positive influence of the Russian nation on the Lithuanians and their culture. The Lithuanian national liberation movement is closely linked with the Russians' struggle against tsarism..$^{46}$ In this respect, Paleckis' booklet Tarybu Lietuva, which was published in Russian in late 1949 in Moscow, deserves some attention. (It received positive reviews in the all-Union press, the first review being in Izvestiya. ${ }^{47}$ ) It is not quite clear why Paleckis decided to publish it outside Lithuania. Lithuanian historiography states that his booklet Советская Литва (Soviet Lithuania) was harshly criticised by Sniečkus and other Party leaders, and obstacles were put in the way of its publication in Lithuanian. ${ }^{48}$ It is possible that Paleckis tried to overcome these obstacles and make use of his contacts in Moscow, thanks not only to being a writer, but also as the chairman of the Presidium of the Supreme Council of the Lithuanian SSR. His chances of getting the book published

${ }^{45}$ Ibid., 1947, p. 7; J. Paleckis, Ka dave tarybu valdžia Lietuvos darbo žmonèms. Kalba į Šiauliu miesto Rytų rinkiminès apygardos rinkëjus (Vilnius, 1947), pp.17-19.

${ }^{46}$ J. Paleckis, Tarybu Lietuvos kelias (Vilnius, 1947), p. 6. Also: J. Paleckis, Ka davé tarybų valdžia Lietuvos darbo žmonéms..., pp. 47-48. Paleckis argued that 'progressive representatives' of the Lithuanian nation were not only revolutionaries but also 'activists of the national movement led by Basanavičius and Kudirka'. In the end, the Soviet government built the Lithuania that 'the progressive representatives of the Lithuanian nation' dreamed about.

${ }^{47}$ Известия, No 306, 1949. A. Golubev was the author of the review.

${ }^{48}$ V. Tininis, Sniečkus. 33 metai valdžioje (Vilnius, 200o), p. 95. 
were helped by the fact that in January 1949 he was awarded the Order of Lenin.

In this work, too, in explaining the history of the Lithuanians, he did not ignore the Lithuanian national movement. It was presented from a slightly different angle than in his speech at the Congress of the Intelligentsia in 1945. The small book not only stressed the positive influence of Russia and Russian culture, but also accentuated the negative impact of Poland and the Poles. In the author's opinion, the Lithuanians, who were weakened by their fight against the Teutonic Order, fell under the influence of the Polish kings and nobles. First, Poland imposed Catholicism, and later political union. The situation of the Lithuanian peasants worsened markedly after the Union of Lublin, while the Lithuanian lords 'renounced their national language and customs. ${ }^{49}$ The Lithuanian language gradually became the language of the peasants, while the nobles and the intelligentsia eventually adopted the Polish language and customs. In the context of this historical concept, the incorporation of Lithuania into the Russian Empire was a positive development. In Paleckis' view, even though it was a backward country, Russia was still more progressive than Poland and its nobles. In general, he thought that the influence of Russian culture on Lithuania was a positive aspect in the nation's development. This was the central idea in the booklet.

Paleckis claimed that 'the first Lithuanian political newspaper Aušra edited by Jonas Basanavičius played an important role in the national liberation movement.' However, cracks appeared in the newspaper that were caused by two political trends: the progressive trend, and the reactionaries (the clerics). This division resulted in the discontinuation of the newspaper. Soon Varpas appeared, a democratic newspaper edited by Vincas Kudirka. The writers Žemaitè and Biliūnas also contributed to the development of democratic culture. Paleckis arrived at the conclusion that, 'supported by the progressive forces of the Russian nation', the Lithuanians managed to survive as a nation despite tsarist policies. (Meanwhile, the Lithuanians in Lithuania Minor gradually began

\footnotetext{
${ }^{49}$ Ю. Палецкис, Советская Литва (Москва, 1949), pp. 13-14.
} 
to lose their 'national awareness'.) Finally, he claimed that 'the part of the Lithuanian nation which had been incorporated into the Russian Empire not only preserved its national character, but also evolved into the core from which the Lithuanian nationality developed into a nation. ${ }^{50}$

In his interpretation of Lithuanian history, he expressed attitudes characteristic of Soviet historiography from that period (for instance, he stressed the positive influence of the Russians and Russia on the development of neighbouring nations). This explains why he portrayed the Lithuanian national movement as being affected by Russian democratic thought, and as a constituent part of the common struggle against tsarism (with the Russians and other Slavic nations). On the other hand, this concept allowed him to speak of Basanavičius and Kudirka as Lithuanian democrats who aimed to liberate the nation from national and social chains, and to digress from the narrow orthodox and class-based assessment of the national movement.

However, the reaction of the Lithuanian Party leadership to Paleckis' booklet and the development of the Lithuanian nation set out in it, was negative, bordering on hostility. We can make two assumptions why this happened.

The first is of a more ideological nature. Paleckis violated an unwritten rule in Party discipline: when the Party and its highest organ passed a decree or a resolution, it became mandatory to all members of the Party, and could not be discussed. Paleckis was disobedient. His book digressed from the political line set out by the Lithuanian Communist Party, and with its attitude to the Lithuanian cultural legacy and the history of the Lithuanian nation. The 'correct' Party line was formulated by Sniečkus at the 6th Congress of the Lithuanian Communist Party in February $1949 . .^{11}$ The first secretary discussed the issue of the 'bourgeois national movement' of the late 19th century. According to Sniečkus, the 'bourgeois explanation' that the national movement engaged

${ }^{50}$ Ibid., pp. $13^{-14}$.

${ }^{51}$ Tiesa, 18 February 1949, No 40. See also Antanas Sniečkus' speech at the 6th Party Congress, LYA LKP, col. 1771, inv. 51, file 216, p. 66-99, 153-156. 
the whole nation was still relevant. In his opinion, this approach ignored the role of the proletariat 'in the liberation struggle of the Lithuanian nation'. In the end, the 'bourgeois national movement' degenerated and became reactionary, because a more progressive movement appeared which was dominated by the proletariat and the Communist Party. Sniečkus maintained that glaring mistakes had been made in the evaluation of the historical past, by surrendering to the influence of bourgeois ideology and the so-called 'single trend', which ignored the theory of the class struggle in the explanation of the nation's history. Albeit indirectly, this criticism was directed at Paleckis. ${ }^{2}$

Various sources point to disagreements between Paleckis and Sniečkus regarding their attitudes to the history of the Lithuanian nation and the importance of the national factor. Sniečkus wrote in his notebooks (dated 1948 and 1949):

'There is nothing in Paleckis about the struggle against the kulaks. He speaks more about the unity of the nation than about the struggle against the kulaks.53

Emphasising the differences between his own and Paleckis' interpretations, he wrote elsewhere in his notes: 'National policies are inseparable from Bolshevik policies [...] it is impossible to speak about a national policy as such separately.' The following words could also have been directed at Paleckis and his position: 'The idealisation of the bourgeois national movement, class-free.' Sniečkus finally set out his disagreements with Paleckis in a letter to Suslov, which was also signed by Vladas Niunka. ${ }^{54}$ They claimed that the history of Lithuania as it was set out in Paleckis' book was entirely wrong. According to them, Paleckis idealised the national movement, and did not write about its bourgeois nature. In general, the little book was a 'ferment of the bourgeois nationalist

${ }^{52}$ Sniečkus strongly criticised various forms of 'bourgeois ideology' such as 'objectivism', 'apolitics' and 'single trend'. LYA LKP, col. 1771, inv. 51, file 216, p. 153-156. Paleckis also gave a speech at the Party congress. However, he tried to avoid sensitive topics. Paleckis' speech at the 6th Party Congress, LYA LKP, col. 1771, inv. 51, file 219, p. 548-566.

${ }^{53}$ Antanas Sniečkus' notes (1948-1949), LYA LKP, col. 16895, inv. 2, file 22, p. 85, 86, 201.

${ }^{54}$ Sniečkus' letter to Mikhail Suslov, 9 January 1950, РГАСПИ, col. 17, inv. 118, file 707, p. 223-228. 
concept'. Paleckis was also accused of anti-Marxism. According to Sniečkus and Niunka, he depicted 'the nationalist Basanavičius' as 'the patriarch of Lithuania'. Meanwhile, positive reviews of the book in the all-Union press (with another review due to come out in the magazine Ogonyok) obstructed the struggle of the Central Committee of the Lithuanian Communist Party against 'the relics of bourgeois ideology' in Lithuania.

Curiously enough, having received this letter of complaint, Moscow did not resort to any serious measures against Paleckis. Suslov thought it would be enough if the Party's theoretical newspaper Kultura i zhizn' published Niunka's critical article about Paleckis' book. ${ }^{55}$ The article was later reprinted in Lithuanian..$^{56}$ Niunka wrote that Paleckis 'analysed the issues of the national movement in an abstract manner', did not stress the roles of different classes, and in general followed 'in the steps of bourgeois historiography'. Paleckis related the beginning of the struggle of the Lithuanian nation for its rights to Aušra, and to Basanavičius, but in Niunka's opinion, did not examine Basanavičius' attitude. Basnavičius was a 'bourgeois liberal', who aimed at the consolidation of the bourgeois dictatorship in Lithuania. Paleckis considered Basanavičius to be a progressive Lithuanian figure. Niunka criticised Paleckis for 'masking' the reactionary role of the bourgeoisie in the Lithuanian national movement, and for belittling the influence of the class struggle and the workers. These attitudes were close to the 'theory of the single trend' that was unmasked and criticised at the 6th Congress of the Lithuanian Communist Party. In other words, Paleckis did not follow the line set out by the Lithuanian Communist Party and its Central Committee. ${ }^{57}$

${ }^{55}$ Communist Party Orgbureau and Secretoriat. Minutes, 27 January 1950, No 480, РГАСПИ, col. 17, inv. 118, file 707, p. 229.

${ }^{56}$ V. Niunka, 'Dèl kai kurių klaidų knygoje Советская Литва', Котипistas, 10 (1950), pp. 46-49.

${ }^{57}$ Sniečkus and other Party members criticised Paleckis again at the 8th Party Plenum on 16-19 November 1950, and again the target was Paleckis' book Советская Литва. Sniečkus maintained that the author's interpretation of the national movement was 'anti-Marxist', and that Paleckis thereby laid 'the foundations for bourgeois nationalism'. Transcript of the plenary session of the Central Committee 
A second interpretation, of a more political nature, of the attack on Paleckis for his attitude towards the national movement, is also possible. Disagreements between Sniečkus and his circle in the Lithuanian Communist Party and Paleckis about the interpretation of the 'national movement' started in 1949. This was the time of the Leningrad Affair. After Andrei Zhdanov's death, the position of Party figures close to him weakened, and in 1949 an attack was launched against Zhdanov's henchmen, such as Aleksei Kuznetsov, a member of the Orgbureau (Organisation-Bureau) of the Central Committee and the secretary for cadres, Pyotr Popkov, a member of the Presidium of the Supreme Council of the USSR, Mikhail Rodionov, the chairman of the Council of Ministers of the RSFSR, and others. Early in March 1949, the academician Nikolai Voznesensky, the chairman of the State Planning Committee (Gosplan), was dismissed from the Politbureau and from the Council of Ministers. Like Zhdanov, they were all closely linked with the Leningrad Party organisation..$^{8}$ In the same year, the 'cleansing' of the Leningrad Party-Soviet apparatus began, with mass dismissals from the Party and from jobs. Finally, in 1950, several prominent Leningraders were executed. ${ }^{59}$ However, the Leningrad Affair did not end there: repressions were carried out against Party members who had belonged to the Leningrad Party organisation at one time or another. Thus, in $195^{\circ}$ purges were begun against Estonian communists such as G. Kedrov, the second party secretary of Estonia, who was from Leningrad. The Estonian Affair included accusations of 'bourgeois nationalism', irresponsibility in the selection of cadres, and the 'pollution' of Party ranks. Nikolai Karotam, the first secretary of the Estonian Communist Party, was accused of passivity in the struggle against 'bourgeois nationalism', the 'protection of nationalists', and the

of the Lithuanian Communist (Bolshevik) Party, LYA LKP, col. 1771, inv. 9o, file 21, p. 58-6o. Minutes No 108 of the Bureau of the Central Committee of the Lithuanian Communist (Bolshevik) Party, 16 November 1950, LYA LKP, col. 1771, inv. 9o, file 128, p. 22-26.

${ }^{58}$ In 1949, Party purges also started in Hungary, Bulgaria, Czechoslovakia and Poland. Famous Party members such as László Rajk, Traycho Kostov and Rudolf Slánský were arrested and executed. Their trials were widely reported in the press.

59 Ленинградское дело, eds. В. Демидов, В. Кутузов (Ленинград, 199о). 
obstruction of their exposure. ${ }^{60}$ Therefore, the assumption can be made that in this dangerous situation, Sniečkus and his circle, who were aware of these repressions and the purges, might have taken advantage of their ideological argument with Paleckis. By accusing Paleckis of bourgeois digressions in ideological issues, and of obstructing the struggle against bourgeois nationalism, Sniečkus not only demonstrated to Moscow his personal diligence and integrity, but also aimed to protect himself against possible persecution and accusations of inactivity.

\section{Political symbolism during late Stalinism. (Paleckis' efforts to influence the creation of the flag of Soviet Lithuania)}

Towards the end of the war, the Soviet leadership initiated a campaign for the design of symbols (flags, emblems and anthems) of federal subjects, that is, republics. One might think that in this way it aimed to show the world the subjection of the republics, and to emphasise the federal structure of the Soviet Union. Moscow determined the essential principles in the design of the symbols: the colour red was to dominate flags, and the themes of friendship of nations and the role of the Party were to prevail in the anthems. (However, the Soviet republics were allowed a certain freedom of 'improvisation', and the process of creating flags and anthems became protracted. ${ }^{61}$ ) The Lithuanian leadership decided first of all to change the anthem, by renouncing Vincas Kudirka's Tautiška giesmé. In the autumn of 1945, the Central Committee of the Lithuanian Communist (Bolshevik) Party formed a commission of seven people to look after the creation of the new anthem. Kazys Preikšas was appointed chairman. ${ }^{62}$ (Paleckis, who was the chairman of the

${ }^{60}$ Nikolai Karotam was removed from his post and forced to leave Estonia. He was not persecuted, however. Karotam lived in Moscow, and worked in a research institute, see: Ленинградское дело..., p. 211.

${ }^{61}$ The flag of the Ukrainian SSR was approved in 1949, of the Byelorussian SSR in 1951, and of the Estonian and the Latvian Soviet republics in 1953. (The flag of Russia was approved only in 1954.) The same happened with the anthems. They were composed and approved during the period 1944 to 1952.

${ }^{62}$ V. Tininis, Komunistinio režimo nusikaltimai Lietuvoje 1944-1953 / The Crimes of the Communist Regime in Lithuania 1944-1953, vol. 3 (Vilnius, 2003), p. 184. 
Presidium of the Supreme Council of the Lithuanian SSR, was also a member of the commission.) It is highly likely that Antanas Sniečkus was behind this decision. The process of creating the words and the music of the anthem was delayed, and it became an urgent issue with the approaching tenth anniversary of Soviet rule in Lithuania. Finally, in late March 1950, the words of the anthem were approved at a sitting of the Central Committee of the Lithuanian Communist (Bolshevik) Party. Following consultations with Moscow, both the music and the text were approved in June. ${ }^{63}$ The new anthem of Soviet Lithuania, the words of which were written by Antanas Venclova, and the music by Balys Dvarionas and Jonas Švedas, was performed on 17 June 1950 at a song festival.

We can presume that Paleckis did not play a prominent role in the creation of the new anthem. Maybe this was because he had fallen out of favour with Sniečkus and his circle, or maybe because he objected to the idea of discarding Kudirka's Tautiška giesme. However, he could not, and did not want to, opt out entirely of creating the symbols of Soviet Lithuania. The circumstances of the creation of the new flag of the Lithuanian SSR point to that. ${ }^{64}$

In the summer of 1952, a special commission of 26 Party and cultural figures was formed to create the new flag of the Lithuanian SSR (they included Sniečkus, Paleckis, Gedvilas, Preikšas, Niunka, A. Trofimov, J. Banaitis, R. Šarmatis, G. Zimanas, T. Černiauskas, J. Žiugžda, K. Korsakas and A. Venclova. ${ }^{65}$ )

It seems that Paleckis started to work on designing the flag earlier, that is, before the formation of the commission. He became involved in working on the flag in the spring of 1952. On 19 March 1952, the Supreme Council of the Lithuanian SSR received the document 'On the Design of the State Flag of the Lithuanian SSR'. It was signed by P. Arkhipov and L. Derbenev, two officials

${ }^{63}$ Documents concerning the anthem of Soviet Lithuania. Antanas Sniečkus' letter to Georgy Malenkov, 22 June 195०, РГАСПИ, col. 17, inv. 132, file 422, p. 1-7.

${ }^{64}$ From 1940, the flag of the Lithuanian Soviet Socialist Republic was red with the symbols of worker solidarity (the hammer and sickle) and the letters 'LTSR' in the top left corner. About the flag of the Lithuanian SSR, see: R. Šarmaitis, 'Vèliavos gimimas', Laikas ir irykiai, 21 (1988) pp. 22-24.

${ }^{65}$ Romas Šarmaitis' manuscript, 17 April 1983, LYA LKP, col. 17635, inv. 1, file 368, p. 22. 
from the Legal Department of the Supreme Council of the Soviet Union. ${ }^{66}$ The document stated that the Legal Department of the Supreme Council of the USSR had received a new design for the flag of Soviet Lithuania, and proposed some 'necessary changes' to it. It noted that the colours and their order in the flag submitted by the Supreme Council of Lithuania (in other words, by Paleckis) were 'analogous to the $1918-1940$ state flag of Lithuania'. The authors of the document stated that 'according to Article 8 of the Constitution of bourgeois Lithuania of 1928, the flag of the state of Lithuania consisted of three equal horizontal stripes: yellow, green and red. The officials in Moscow wrote that these colours and their order, which in fact replicated the flag of the Republic of Lithuania, were wrong and had to be changed. The 'dominant colour' in the flag of Soviet Lithuania had to be red: the red stripe was to be at the top of the flag (a design existing in the flags of other Soviet republics), and not at the bottom as suggested in the design submitted.

In April 1953, 54 designs for the flag of Soviet Lithuania were submitted to the commission. Paleckis submitted 11 versions. ${ }^{67}$ They show that he took Moscow's demands into account, and made red the dominant colour of the flag. And yet one of Paleckis' designs stood out from the others. ${ }^{68}$ It was the only design that attempted to preserve the colours of the flag of the Republic of Lithuania, even if in a peculiar way: two red stripes at the bottom and the top of the flag were separated by a narrower yellow stripe, and there was a green triangle on the left-hand side ... The commission chose the design by the artist Vytautas Palaima. His flag consisted of three stripes: red, white and green. The Central Committee of the Lithuanian Communist Party soon endorsed this design.

\footnotetext{
${ }^{66}$ The document was first sent to A. Gorkin, the secretary of the Presidium of the Supreme Council of the Soviet Union, and then forwarded to Paleckis, LYA LKP, col. 1771, inv. 133, file 12, p. 270-271.

${ }^{67}$ All 11 drafts were signed as 'Paleckis' proposals'. The projects of the flag of Soviet Lithuania, LYA LKP, col. 3377 , inv. 58, file 446.

${ }^{68}$ Ibid., p. 42
} 


\section{Conclusions}

1. Paleckis believed that it was possible to match the 'Soviet' with the 'national', and made efforts to render Soviet Lithuania more Lithuanian. His speeches and works emphasised the need to take into account 'specific' Lithuanian conditions while creating the socialist order. According to him, the mechanical transfer of experience in creating a new social order from other Soviet republics and nations to Lithuania would be impossible. On the other hand, it should be noted that, just like other leaders of the Lithuanian Communist Party, he stressed the necessity for the struggle against 'bourgeois nationalists', spoke of the need for inculcating Soviet patriotism, and emphasised the positive role of the Russian nation in Lithuania's history. All these ideas were closely intertwined.

2. Paleckis was an ardent advocate of the 'employment of bourgeois specialists', and cooperation with Lithuania's interwar intelligentsia. According to him, they played an important role in 'the rebuilding of Soviet Lithuania'. He was also convinced that a knowledge of the language and the local conditions, the possibility to communicate and to carry out social duties among the local population, were qualities that were important for working in Lithuania. He was critical of the new arrivals from other Soviet republics. According to him, these newcomers were oblivious of the conditions in Lithuania, and of the country's past, and so were distrustful of everybody. Paleckis observed that the ongoing 'cleansing' of unreliable personnel simultaneously resulted in their 'de-Lithuanianisation', and, as a consequence, in lower numbers of Lithuanian executive cadres. For this reason, it was crucial to 'promote' local national cadres.

3. Paleckis' notion of history was based not only on the idea of the class struggle and the struggle for 'the people's liberation from social oppression', but also on the struggle for the liberation of the Lithuanian nation from national oppression. These two stages in the liberation of the Lithuanians were closely related. Within this concept of history, the period of 'national liberation' was an important stage in the history of the nation. The nation's social and national liberation was organically crowned by the creation of Soviet Lithuania. 
4. An analysis of Paleckis' activities shows that the Lithuanian Party leadership did not support his ideas. He was often severely criticised. In general, it can be argued that in the late period of Stalinism, the 'window of opportunity' for national communism in Lithuania was finally closed. Tendencies towards unification and Russification became increasingly prevalent in politics. Thus, in this political-cultural context, Paleckis was the type of communist that could be called an 'indigenous Lithuanian communist'.

Author Details

Vladas Sirutavičius is a senior researcher at the Lithuanian Institute of History. $\mathrm{He}$ is the author of several monographs, including Lietuvos istorija. Sajūdis: nuo „persitvarkymo“ iki Kovo 11-osios (The History of Lithuania. Sajūdis: from Perestroika to 11 March, Vilnius, 2008, with Č. Laurinavičius), Lietuviai ir Lietuvos lenkai, Lietuva ir Lenkija 1988 - 1994 (Lithuanians and Lithuanian Poles, Lithuania and Poland 1988-1994, Vilnius, 2017). His current area of interest is late Stalinism and the beginning of de-Stalinisation in Lithuania, the culture and formation of the Soviet/Lithuanian identity.

Address: Lithuanian Institute of History, 5 Kražių St, Vilnius LT-o11o8, Lithuania Email: sirutavicius@yahoo.com; vladas.sirutavicius@istorija.lt

\section{Bibliography}

BEHRENDS, Jan C. 'Nation and Empire: Dilemmas of Legitimacy during Stalinism in Poland (1941-1956)', Nationalities Papers, No 3 (2009), pp. $443-466$.

BRANDENBERGER, David. National Bolshevism. Stalinist Mass Culture and the Formation of Modern Russian National Identity, 1931-1956 (Cambridge, London, 2002).

BRZEZINSKI, Zbignew. The Soviet Bloc. Unity and Conflict (Harvard, 1981).

KEMP, Walter A. Nationalism and Communism in Eastern Europe and Soviet Union. A Basic Contradiction? (London, 1999).

GRIGALAVIČIUS, J. Kai Lietuvoje šeimininkavo stalinistai (Vilnius, 1991).

GRYBKAUSKAS, Saulius. Sovietine nomenklatūra ir pramoné Lietuvoje 1965-1985 metais (Vilnius, 2011).

IVANAUSKAS, Vilius. Lietuviškoji nomenklatüra biurokratinëje sistemoje. Tarp stagnacijos ir dinamikos (1968-1988) (Vilnius, 2011). 
KAŠAUSKIENĖ, Vanda. Istorijos spactuose. Justo Paleckio gyvenimo ir veiklos bruožai 1899-1980 (Vilnius, 2014).

MACE, James E. Communism and the Dilemmas of National Liberation: National Communism in Soviet Ukraine, 1918-1933 (Cambridge, 1983).

MALIA, Martin. The Soviet Tragedy. A History of Socialism in Russia, 1917-1991 (New York, Oxford, 1994).

MEVIUS, Martin. Agents of Moscow. The Hungarian Communist Party and the Origin of Socialist Patriotism 1941-1953 (Oxford, 2004).

MOTYL, Alexander. Sovietology, Rationality, Nationality: Coming to Grips with Nationalism in the USSR (New York, 1990).

NIUNKA, Vladas. 'Dèl kai kurių klaidų knygoje Sovietskaya Litva' Komunistas, No 10 (1950).

PIPES, Richard. The Formation of the Soviet Union. Communism and Nationalism 1917-1923 (Cambridge, London, 1997).

PALECKIS, Justas. Tarybų Lietuvos kelias (Vilnius, 1947).

PALECKIS, Justas. Ka dave tarybu valdžia Lietuvos darbo žmonèms (Vilnius, 1947).

PALECKIS, Justas. Pergalès saliutas (Vilnius, 1985).

PALECKIS, Justas. Ieškojome tikrų kelių (Vilnius, 1987).

PONS, Silvio. 'Stalin and the European Communists after World War Two (1943-1948)' in: Post-War Reconstruction in Europe. International Perspectives, 1945-1949, eds. M. Mazover et al. (New Haven, London, 2011), pp. 121-138.

REE, Eric van. 'The Concept of "National Bolshevism": An Interpretative Essay', Journal of Political Ideologies, No 3 (2001), pp. 292-293.

RUDOKAS, Jonas. 'Tarybinè Vilnijos polonizacija 1950-1956 metais', Gairès, No 7 (2011), p. 16-21.

SIRUTAVIČIUS, Vladas. 'Tautinis komunizmas ir jo raiška. Istoriografiniai problemos aspektai', Istorija, No 3 (2013), p. 48-58.

SIRUTAVIČIUS, Vladas. 'National Bolshevism or National Communism: Features of Sovietization in Lithuania in the Summer of 1945 (The First Congress of the Intelligentsia)', The Hungarian Historical Review, No 1 (2015), p. 3-28.

SIRUTAVIČIUS, Vladas. 'Istoriko pamąstymai apie Algirdo Juliaus Greimo tautinio komunizmo interpretacijas', Darbai ir dienos, Vol. 68 (2017), p. 129-144.

SIRUTAVIČIUS, Vladas. 'Politinè simbolika stalininèje Lietuvoje. LSSR himnų istorijos 1944-1950 m.' Kultūros barai, No 11 (2018).

SYGKELOS, Yannis. 'The National Discourse of the Bulgarian Communist Party on National Anniversaries and Commemorations (1944-1948)', Nationalities Papers, No 4 (2009), pp. 425-442. 
SNIEČKUS, Antanas, GEDVILAS, Mykolas. Lietuviu tauta kovoje už laimingą ateiti (Kaunas, 1947).

STRAVINSKIENĖ, Vitalija. 'Lietuvių ir lenkų santykiai Rytų ir Pietryčiu Lietuvoje: 1944 m. antra pusẻ - 1953 m.', Lietuvos istorijos metraštis, 2007/2 (2008), p. 71-87.

STREIKUS, A. 'Sovietinio režimo pastangos pakeisti Lietuvos gyventojų tautini identitetą', in: Genocidas ir rezistencija, Vol. 1 (2007).

ŠADŽIUS, Henrikas. 'VKP (b) CK Lietuvos biuro veikla organizuojant tautinio pasipriešinimo slopinimą', Lietuvos istorijos metraštis 1997 (Vilnius, 1998).

ŠARMAITIS, R. 'Vèliavos gimimas' Laikas ir ìvykiai, 21 (1988).

TAMOŠAITIS, Mindaugas. 'Justas Paleckis ir jaunieji valstiečiai liaudininkai', Vilniaus istorijos metraštis (Vilnius, 2007).

Tarybų Lietuvos inteligentijos uždaviniai, red. J. Šimkus (Vilnius, 1947), pp. $45^{-69}$.

TININIS, Vytautas. Sovietine Lietuva ir jos veikëjai (Vilnius, 1994).

TININIS, Vytautas. Sniečkus. 33 metai valdžioje (Vilnius, 200o).

TININIS, Vytautas. Komunistinio režimo nusikaltimai Lietuvoje 1944 1953/The Crimes of the Communist Regime in Lithuania 1944-1953, Vol. 3 (Vilnius, 2003).

TISMĂNEANU, Vladimir. Stalinizm na każda okazję. Polityczna historia rumuńskiego komunizmu (Kraków, 2010).

TRUSKA, Liudas. Lietuva 1938-1953 metais (Kaunas, 1995).

ZAREMBA, Marcin. Komunizm, legitymizacja, nacjonalizm. Nacjonalistyczna legitymizacja wtadzy komunistycznej w Polsce (Warszawa, 2001).

ЛАУРИНАВИЧЮС, Чесловас. 'Вводная статья', in: СССР и Литва в годы второй мировой войны. Сборник документов, сост. А. Каспаравичюс, Ч. Лауринавиюс, Н. Лебедева, т. 2 (Вильнюс, 2012).

ЗУБКОВА, Елена. Прибалтика и Кремль 1940-1953 (Москва, 20о8). ПАЛЕЦКИС, Юстас, Советская Литва (Москва, 1949). 


\section{TARP TAUTINIO IR PARTIKULIARARAUS KOMUNIZMO. JUSTO PALECKIO POLITINĖS BIOGRAFIJOS BRUOŽAI, 1944-1953 M.}

Santrauka

\section{VLADAS SIRUTAVIČIUS}

Straipsnyje aptariama Sovietinės Lietuvos Aukščiausiosios tarybos prezidiumo pirmininko Justo Paleckio veikla vėlyvojo stalinizmo metais. Straipsnyje formuluojama prielaida, kad Paleckio veikloje galima aptikti nuostatu, artimų Vidurio Europos tautiniams komunistams (bent jau iki 1947 m.). Straipsnyje taip pat pažymima, kad Paleckio galvosenoje ir elgesyje dar aktyviau reiškėsi tarybinis lietuviškas vietininkiškumas (partikuliarizmas). Paleckis tekstuose bei kalbose stengėsi pabrèžti Lietuvos istorinès raidos specifiką, skirtumus nuo kitų sovietinių respublikų. Valstybingumo, taip pat ir „buržuazinio”, tradicija darẻ Lietuvą unikalia respublika. Taigi, kuriant sovietinę struktūrą, ị tą aplinkybę būtina atsižvelgti. Siekiant padaryti tarybų valdžią patrauklesnę, įtvirtinti jos teisėtumą, pakelti jos autoritetą būtina patraukti tarpukario lietuvių inteligentiją ir plètoti lietuvių kalbą bei kultūrą. Paleckis lietuvių tautos istorijoje stengėsi organiškai susieti lietuvių liaudies vadavimąsi iš išnaudotojų , jungo", kitais žodžiais tariant, kovą už socialinį teisingumą, su vadavimusi iš „nacionalinio jungo” arba su tautinio atgimimo laikotarpiu. Ši procesą istoriškai „vainikavo" socialistinès santvarkos sukūrimas Lietuvoje. Tokia „organistinë” istorijos samprata buvo būdinga ir kai kuriems Vidurio Europos šalių, atsidūrusių Sovietų Sajungos įtakos sferoje, tautiniams komunistams. Svarbu ir tai, kad Paleckis bandė ị sovietinès Lietuvos simboliką įtraukti nacionalinius lietuviškus elementus. Jis aktyviai kèlè klausimą dèl Vinco Kudirkos „Tautiškos giesmės” paskelbimo sovietinès Lietuvos himnu, rūpinosi LSSR vèliavoje išsaugoti tautines spalvas. Paleckio veiklos analizė atskleidè, kad Lietuvos komunistų partijos vadovybẻ Paleckio idẻjų bei iniciatyvų neparẻmė. LSSR AT prezidiumo pirmininkas partiniuose forumuose dèl savo pažiūrų buvo ne kartą griežtai kritikuotas. Apibendrinant galima teigti, kad vẻlyvojo stalinizmo metais politinių ,galimybių langas” tautinio komunizmo raiškai galutinai užsivẻrè. Politikoje, viešame gyvenime èmẻ dominuoti unifikacinès bei rusifikacinės tendencijos. Tokiame politiniame socialiniame kontekste Paleckis reprezentavo komunisto tipą, kuri ko geriausiai tiktų vadinti vietiniu lietuvišku komunistu. 